\title{
Conjunctival Chemosis: A Case Series of Systemic Causes
}

\author{
David P. Roncone, \\ OD, FAAO \\ Cleveland VA \\ Medical Center \\ Scott A. Anthony, \\ OD, FAAO \\ Cleveland VA \\ Medical Center
}

\begin{abstract}
ABSTRACT

Conjunctival chemosis is a common ophthalmic finding that presents with a wide range of severities, symptoms, signs, and underlying etiologies. Although most cases of conjunctival chemosis are ocular in nature (allergy, infection, irritation), atypical presentations, such as dusky conjunctival hue, corkscrew conjunctival veins, and periorbital edema, should prompt further investigation for a systemic cause. In atypical cases, a review of the patient's medical history and medications, physical examination of the patient's heart and lungs, and determination of the patient's vitals (i.e., blood pressure, pulse, weight) are crucial for identifying a potential systemic source. This article reviews systemic causes of conjunctival chemosis and provides case examples to demonstrate evaluative and management techniques for optometrists to make a distinction between ocular and systemic conjunctival chemosis.
\end{abstract}

\section{KEY WORDS:}

conjunctival chemosis, periorbital edema, cutaneous, superior vena cava syndrome, hypervolemia

\section{INTRODUCTION}

Conjunctival chemosis, which is edema of the conjunctiva and the caruncle, is a common ophthalmic complication that presents with a wide range of severities, symptoms, signs, and underlying etiologies. Common clinical characteristics include diffuse translucent swelling of the bulbar conjunctiva and caruncle, folds or rugae of the conjunctival cul-de-sac, and associated tarsal conjunctival papillae. ${ }^{1,2}$ Atypical features may include conjunctival congestion and dusky colored chemosis. To determine its etiology, it is crucial to use the ocular history, symptoms and slit lamp biomicroscopy signs (chemosis severity and color, and accompanying ocular signs). Although most cases of conjunctival chemosis are ocular in nature (allergy, infection, irritation), atypical presentations should prompt further investigation for a systemic cause. In atypical cases, a review of the patient's medical history and medications, physical examination of the patient's heart and lungs, and determination of the patient's vitals (i.e., blood pressure, pulse, weight) are crucial for identifying a potential systemic source. Systemic diseases that manifest conjunctival chemosis can be serious and even life-threatening, highlighting the importance of identifying this association. This article reviews systemic causes of conjunctival chemosis and provides case examples to demonstrate evaluative and management techniques for optometrists to distinguish between ocular and systemically derived conjunctival chemosis.

\section{CASE REPORTS}

\section{Case 1:}

A 59-year-old African-American male reported for a routine eye exam with stable vision and good comfort OU. The patient's ocular history was pertinent for vitreous degeneration OU, blepharitis OU, and mild hypertensive retinopathy OU. He had no history of ocular trauma or surgery, recent exposure to allergens, or history of seasonal allergies. His medical history was pertinent for benign essential hypertension, atrial fibrillation without recurrence following treatment with direct current cardioversion surgery, 
aneurysm of ascending aorta, bipolar affective disorder, sickle cell trait, displacement of intervertebral disc, adrenal cortical adenoma, chronic back pain, and polysubstance abuse (alcohol, marijuana, cocaine).

His medications included albuterol oral inhaler, aspirin 81mg, carvedilol, divalproex, ibuprofen, omeprazole, sildenafil citrate, and tamsulosin. Allergies included haloperidol, lurasidone, and peanuts.

Ocular examination revealed corrected visual acuities of 20/20 OD and OS. Pupils, extraocular motility, cover test and confrontation fields were normal in both eyes. Gross physical examination revealed 1+ edema of the superior and inferior orbital rim OU, venous engorgement of the right jugular vein, dyspnea, dry and non-productive cough, and pitting edema of the right and left ankles. Elevated blood pressure (160/105 $\mathrm{mmHg}$ ) and normal pulse (84 beats per minute) were noted. Slit lamp biomicroscopy revealed eyelid collarettes. The conjunctiva revealed $3+$ dusky chemosis from 6 to 9 o'clock OD and 1+ dusky pink chemosis from 3 to 4 o'clock OS (Figure 1). The cornea had arcus OU, with a tear breakup time of 10 seconds. The crystalline lens showed 1+ cortical opacities OU. Intraocular pressures by applanation were $16 \mathrm{mmHg}$ OD and $14 \mathrm{mmHg}$ OS at 9:55 A.M. Dilated fundus examination was significant for posterior vitreous detachment OU and tortuous retinal blood vessels consistent with hypertensive retinopathy OU.

Figure 1: Case 1-Diffuse conjunctival chemosis secondary to hypervolemia from acute decompensated heart failure with prolapse of bulbar conjunctiva over the lid margin

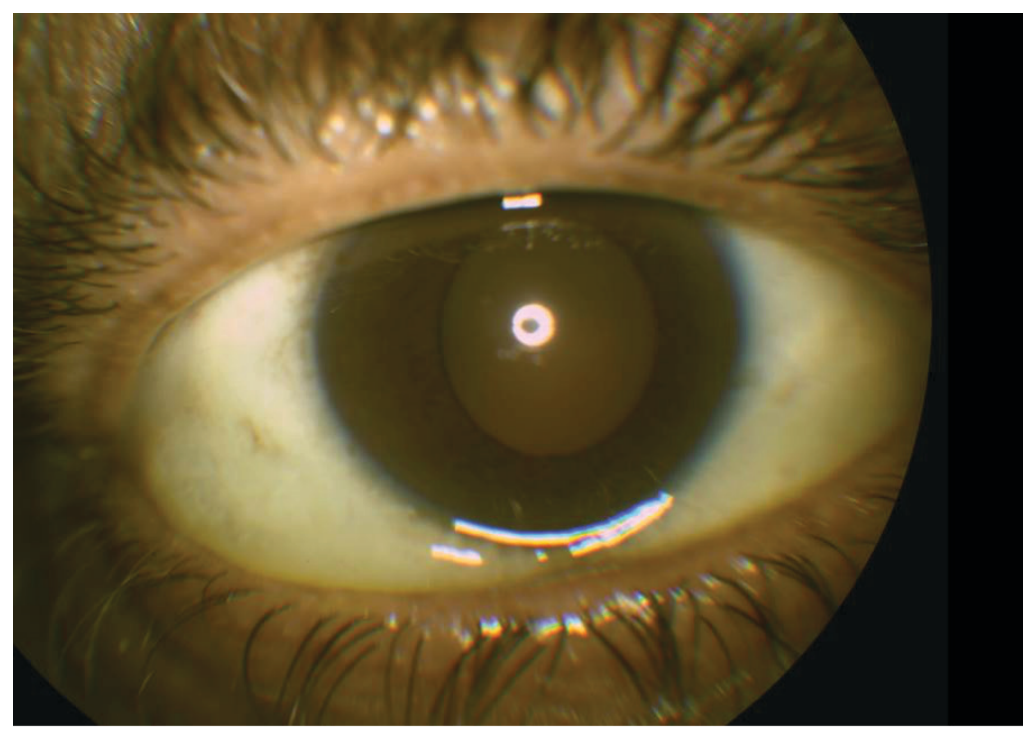

The patient was diagnosed with atypical conjunctival chemosis. Due to his cardiac risk factors (hypertension, atrial fibrillation, tobacco use, former alcohol and illicit drug abuse), ocular signs (dusky pink conjunctival chemosis OU, periorbital edema OU), systemic signs (venous engorgement of the right jugular vein and anasarca of the right and left ankles), and symptoms (dyspnea, dry and non-productive cough), the patient was suspected to have chemosis secondary to hypervolemia due to acute decompensated heart failure. The patient was sent to the emergency department for further medical evaluation and blood work, to include renal and liver panels and cardiac biomarkers (B-type natriuretic peptide, troponin-I, and creatinine kinase). The results of the renal and liver panels were normal; however, elevated B-type natriuretic peptide levels $(2,277 \mathrm{pg} / \mathrm{ml})$ and troponin-I $(0.14 \mathrm{ng} / \mathrm{ml})$ confirmed a diagnosis of acute decompensated heart failure by cardiology, and the patient was admitted to the hospital for further evaluation and treatment. After his blood pressure was stabilized (135/90 mmHg) using intravenous hydralazine, furosemide, and acetaminophen, he was discharged from the hospital with newly prescribed atorvastatin calcium, lisinopril, and spironolactone. A cardiovascular work-up one week later, which included coronary angiogram and trans-thoracic echocardiogram, confirmed right- and left-sided heart failure, which the patient opted to medically manage with oral anti-coagulant and an anti-arrhythmic. One month later, cardiovascular stability and resolved conjunctival chemosis were confirmed by cardiology and optometry.

Case 2:

A 67-year-old African-American male presented for his yearly diabetic eye exam with stable vision OU. He reported itchy skin and painless left eye swelling since starting daily amlodipine $5 \mathrm{mg}$ ten months previously for hypertension. His ocular history included meibomian gland dysfunction, dry eye syndrome, mild hypertensive retinopathy 
OU, type 2 diabetes mellitus without ophthalmic complications OU, and mild cataracts OU. He had no history of ocular trauma or surgery, and no recent exposure to allergens. His medical history was pertinent for hypertension, hyperlipidemia, type 2 diabetes mellitus with neuropathy, obesity, sleep apnea, male erectile disorder, benign hypertrophy of the prostate, spinal stenosis of the lumbar region, osteoarthritis, and gastroesophageal reflux disease.

His medications included artificial tears, fosinopril, terazosin, simvastatin, amlodipine besylate, omeprazole, vardenafil, aspirin, tramadol, metformin, hydrochlorothiazide, and cholecalciferol (vit D3).

Ocular examination revealed corrected visual acuities of 20/20 OD and OS. Pupils, extraocular motility, cover test and confrontation fields were normal in both eyes. Gross physical examination was remarkable for peripheral pitting edema of both ankles. Mildly elevated blood pressure $(162 / 91 \mathrm{mmHg})$ and normal pulse (75 beats per minute) were noted. Slit lamp biomicroscopy of the eyelids revealed turbid expressions of the meibomian glands OU, conjunctival racial melanosis OU, nasal pterygium OU, and mild temporal conjunctival chalasis OD. The left eye revealed 3+ translucent bulbar conjunctival chemosis extending from the limbus to the fornix with sparing of the superior quadrant OS (Figure 2). The patient confirmed habitually sleeping in a decubitus position on his left side. The cornea, anterior chamber, iris, and lens were unremarkable OU. Tear break-up time was 7 seconds. Intraocular pressures by applanation were $15 \mathrm{mmHg}$ OD and $16 \mathrm{mmHg}$ OS. Dilated fundus examination revealed tortuous retinal blood vessels consistent with hypertensive retinopathy OU.

Figure 2: Case 2-Diffuse conjunctival chemosis secondary to amlodipine allergy with translucent conjunctival edema and caruncle swelling

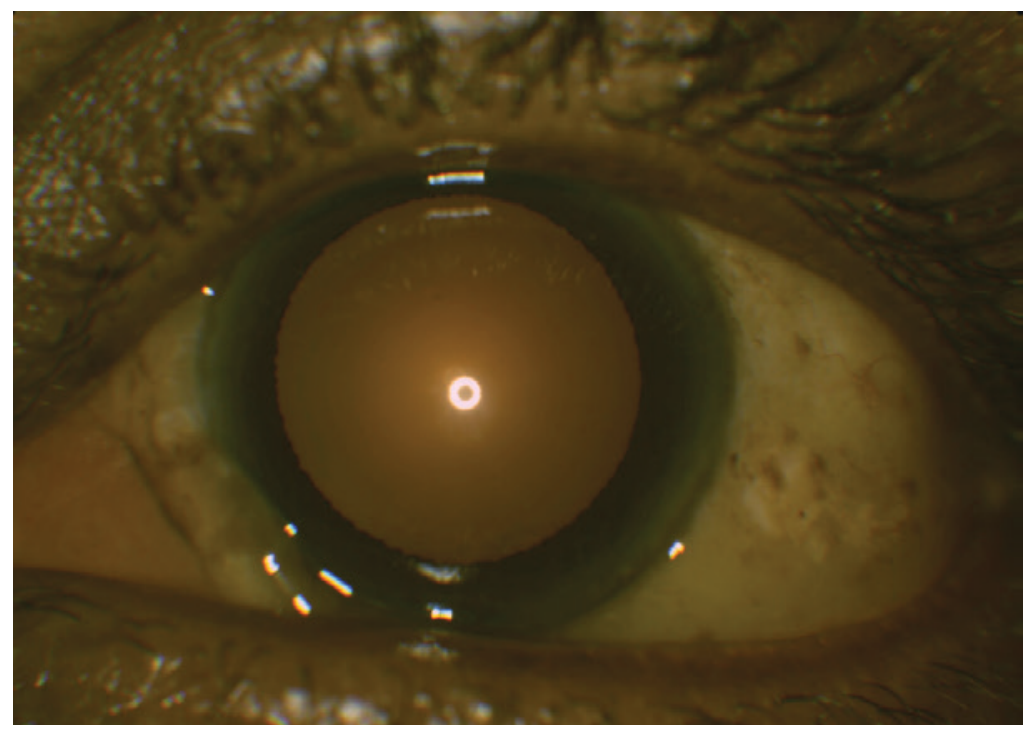

The patient was advised to continue with warm compresses b.i.d. OU and artificial tears t.i.d. OU. He was told that his conjunctival chemosis required a non-urgent consult to his primary care physician for suspected amlodipine allergy, especially after the patient confirmed itchy skin. The patient was advised to continue amlodipine, as a hypersensitivity reaction to this medication was a diagnosis of exclusion. The patient was also referred to cardiology for evaluation, due to his cardiac risk factors (diabetes, hypertension, hyperlipidemia, and sleep apnea). Cardiology evaluation with coronary angiogram, trans-thoracic echocardiogram, renal and liver panels, and cardiac biomarkers (B-type natriuretic peptide, troponin-I, and creatinine kinase) revealed ischemic heart disease without acute decompensated heart failure. Amlodipine allergy was confirmed due to cardiopulmonary stability and non-pitting anasarca of the ankles. Amlodipine was discontinued and carvedilol was initiated in its place. At the one-month follow-up cardiology and eye examination, the patient's blood pressure was well-controlled and the conjunctival chemosis was resolved.

\section{DISCUSSION}

\section{Anatomy}

During episodes of conjunctival chemosis, the bulbar conjunctiva is primarily affected. The bulbar conjunctiva is a loosely connected, semitransparent mucous membrane overlying the anterior globe between the superior and inferior fornices and extending to the corneal limbus. ${ }^{3}$ Within the stromal layers of the bulbar conjunctiva lies a matrix of 
lymphatic vessels (sub-mucosa) and blood vessels (deeper sub-mucosa) where extracellular fluids may accumulate. This space of loose attachment between the bulbar conjunctiva and underlying Tenon's layer and sclera is where fluid build-up occurs during episodes of inflammatory, infectious, or vascular events. ${ }^{4}$ Since the palpebral conjunctiva is more tightly adherent to the tarsus, edema is less pronounced at this level and may simply present with papillae.

\section{Ocular History}

A thorough patient ocular history can be revelatory for patients who present with conjunctival chemosis since most cases have an underlying ocular etiology with a distinct mechanism of action (Table 1).,5-19 Common ocular etiologies include foreign body (conjunctival, corneal, eyelid), mechanical trauma (eye rubbing, blunt-force injury, trichiasis, tarsal plate concretion cysts, papillae, or follicles), acute glaucoma, ocular infection (conjunctivitis, keratitis, scleritis, endophthalmitis), or orbital infection (orbital cellulitis), allergy (conjunctivitis) and ocular inflammatory disorders (episcleritis, scleritis, uveitis). ${ }^{12-15,18}$

Adverse toxic effects from ophthalmic drugs, termed medicamentosa or toxic keratoconjunctivitis, ${ }^{20}$ may also produce conjunctival chemosis. Numerous ophthalmic medications have been implicated in this type of reaction (Table 2) ${ }^{16-18,21-27}$ Specific patterns of corneal, eyelid, and other conjunctival findings (follicular papillary reactions, symblepharon and/or fornix shortening, scarring, periocular skin hyperemia/induration/scaling) may help to confirm this etiology (Table 3). ${ }^{16,17,21,28}$ Bulbar conjunctival injection may be greater inferiorly than superiorly, and corneal epitheliopathy may be greatest inferonasally because of increased contact time with the pharmaceutical. ${ }^{28,29} \mathrm{Clinical}$ signs usually take several weeks to develop ${ }^{18}$ and unilateral or asymmetric conjunctival chemosis is not uncommon with medicamentosa or other toxic exposures. ${ }^{17}$

\section{Slit Lamp Biomicroscopy Clinical Signs}

Detailed slit lamp biomicroscopy is crucial for diagnosing and managing conjunctival chemosis. ${ }^{1,2}$ The primary characteristics of conjunctival edema include translucent swelling of the bulbar conjunctiva, folds or rugae of the cul-de-sac, and associated tarsal papillae. ${ }^{1}$ Caruncular edema presents as a swollen hyperemic caruncle, which at times can appear dry. Mild bulbar conjunctival chemosis is more likely to present as small redundant folds of conjunctiva extending past the mucocutaneous junction of the lower eyelid, while severe cases reveal prolapsed conjunctiva across the lower eyelid. ${ }^{2}$ Although conjunctival chemosis may present unilaterally, bilateral, and symmetric involvement could indicate systemic etiology. The jelly-like conjunctival appearance is either pale and colorless, or dusky red. ${ }^{1}$ Cases that are pale and colorless are usually due to non-venous congestion-related etiologies ${ }^{1}$, as seen in ocular trauma, ocular infections and inflammatory conditions, chemical burns and contact hypersensitivity reactions. Blunt force and chemical ocular trauma are both ocular emergencies that require ophthalmology consultation if conjunctival chemosis is suspected to be accompanied by scleral rupture or alkaline chemical burns. ${ }^{5}$ Conjunctival chemosis that takes on a dusky red appearance and is accompanied by prominent conjunctival venous dilation is more likely to originate from a systemic venous blockage or congestion etiology. ${ }^{1}$ Conjunctival chemosis accompanied by corkscrew conjunctival veins suggests the possibility of retrograde venous flow, termed arterialization. Ninety percent of patients with arterialization of the conjunctival veins have carotid cavernous sinus fistulas. ${ }^{30}$ Eyelids should be everted during slit lamp biomicroscopy to rule out a mechanical or traumatic etiology (foreign bodies, trichiasis, palpebral conjunctival and tarsal plate cysts, papillae, or follicles). It can be helpful to test corneal sensitivities if herpetic eye disease and neurotrophic keratopathy are suspected.

\section{Symptomatology}

In the absence of an underlying ocular etiology for conjunctival chemosis, a comprehensive medical history, a review of the symptomology and identification of any systemic hypersensitivity reactions to drugs, foods, chemical exposures, contact lens solution, cosmetics (skin and hair products), and illicit drugs can help determine if a systemic etiology exists (Table $4 \mathrm{a}-\mathrm{e}^{6,18,30-52}$ and Table $5^{2,6,18,33,40,42,49,53-58}$ ). The acuteness or chronicity of symptoms can help differentiate a localized ocular versus systemic cause of conjunctival chemosis. An acute onset of conjunctival chemosis is usually indicative of a hypersensitivity response (Table 2).,16-18,21-27 A subacute or chronic onset of conjunctival chemosis may have numerous etiologies, including localized ocular tissue responses (thyroid eye disease, chronic allergic conjunctivitis, ocular or eyelid surgery, trauma), increased systemic vascular permeability (allergic conditions, infections including meningitis, vasculitis), increased venous pressure (superior vena cava syndrome, heart failure), and decreased plasma oncotic pressure (nephrotic syndrome, hepatic disease). 2,18,59

\section{SYSTEMIC ETIOLOGIES OF CONJUNCTIVAL CHEMOSIS}

\section{Hypersensitivity Reactions}

Numerous systemic medications have been implicated in hypersensitivity-related conjunctival chemosis (Table 2). ${ }^{16-18,21-27}$ Although drug-induced hypersensitivity reactions account for $36.2 \%$ of anaphylaxis, food allergies remain the most common cause $(49.7 \%)$ and recent food consumption should be investigated..$^{33}$ Ocular signs may 
have concurrent dermatological signs and symptoms. Skin reactions (intense itching, flushing, eye or lip-tongueuvula edema) and urticaria (rash sometimes accompanied by superficial dermal edema) are the most common presenting hypersensitivity symptoms, with a higher prevalence with food ( $90.9 \%$ and $86.9 \%$, respectively) than with drugs (69.4\% and $66.7 \%$, respectively)..$^{33}$ Although dyspnea presents equally in each group, respiratory symptoms (wheezing, stridor, hypoxemia) are more common with food allergies, while cardiovascular symptoms (syncope, hypotension, urinary incontinence, chest discomfort) are more common with drug allergies. ${ }^{33}$

\section{Non-hypersensitivity Reactions}

Systemic etiologies of conjunctival chemosis not attributable to hypersensitivity reactions include cavernous sinus disease (carotid cavernous sinus fistula, carotid cavernous sinus thrombosis), thyroid disease (hyperthyroidism, Grave's disease), superior vena cava syndrome, and hypervolemia (with its various underlying systemic conditions) (Table 4b-e). ${ }^{6,18,30-52}$

\section{Cavernous Sinus Disease}

Cavernous sinus disease (carotid cavernous sinus fistula and carotid cavernous sinus thrombosis) may present with conjunctival chemosis, in addition to numerous cranial nerve deficits.

Carotid cavernous sinus fistula is an anomalous connection between the venous system of the cavernous sinus and the internal carotid artery or its meningeal branches, or meningeal branches of the external carotid artery. ${ }^{60}$ Conjunctival chemosis will present in $42 \%$ of patients with a carotid cavernous sinus fistula, and is characterized by the pathognomonic finding of corkscrew arterialization of the conjunctival veins $(93 \%) .{ }^{30}$ Additional clinical signs that occur as a result of the congestive effects of abnormal blood flow from within the cavernous sinus include proptosis (84\%), decreased visual acuity (43\%), cranial nerve palsy (52\%), and bruit (28\%). ${ }^{30}$

Carotid cavernous sinus thrombosis is an aseptic (surgery, trauma) or septic (sinusitis, otitis, odontogenic, facial faruncles, erysipelas) blood clot (thrombus or embolism) that travels to the cavernous sinus. ${ }^{61}$ Acute signs presenting from congestion or blockage of the venous system include proptosis, ptosis, and chemosis. ${ }^{32}$ These patients have a higher likelihood of a cranial nerve palsy than carotid cavernous sinus fistula patients (80-100\% versus 52\%), and the abducens nerve is affected most often (73\%). ${ }^{32}$ However, key differentiating symptoms of periorbital edema, headache, lethargy, and altered sensorium (50-80\%) are typically observed with a cavernous sinus thrombosis. ${ }^{32}$

\section{Hyperthyroidism}

Hyperthyroidism can result in conjunctival chemosis secondary to fluid accumulation of glycosaminoglycans in connective tissue, resulting in edema and inflammation of the extraocular muscles, orbital connective tissue and fat, increased orbital volume, and decreased venous and lymphatic drainage. ${ }^{49,53}$ Investigations for an associated hyperthyroid condition should account for the patient's age. Younger patients $(<50$ years) are classically more symptomatic than older patients ( $\geq 70$ years), but have the same core symptoms as their elders: tachycardia ( $96 \%$ versus $71 \%$ ), fatigue ( $84 \%$ versus 56\%), and weight loss (51\% versus 50\%). ${ }^{33,34}$ Additionally, younger patients are more likely to have other symptoms, including neurological symptoms, dyspnea, and polydipsia (Table 4). ${ }^{6,18,30-52}$ Twenty-five to forty percent of thyroid patients have thyroid orbitopathy, ${ }^{35,36}$ with common symptoms of pain (30\%), lacrimation (20.8\%), diplopia at initial presentation (16.6\%), photophobia (15.8\%), and blurred vision (7.5\%). ${ }^{37}$

\section{Superior Vena Cava Syndrome}

Obstruction or compression of the superior vena cava, a large vein that carries deoxygenated blood from the upper extremities, head, neck, and thorax to the right atrium, can lead to decreased venous drainage, termed superior vena cava syndrome..$^{40}$ Its most common sign is facial or neck swelling $(82 \%)^{40}$ that is aggravated in the horizontal position. Patients may also complain of upper-extremity swelling (68\%), dyspnea (66\%), and cough (50\%). ${ }^{40}$ Sixty percent of superior vena cava syndrome cases are due to malignant etiologies, specifically bronchogenic carcinoma (small cell and non-small cell lung cancer) (46\%), lymphoma (8\%) and germ cell tumors (8\%). ${ }^{40}$ Superior vena cava syndrome can also result from other etiologies in $40 \%$ of cases, such as medical devices (intravascular devices, dialysis catheters, pacemaker wire, Hickman catheter), and fibrosing mediastinitis (secondary to lymphoma, histoplasmosis, tuberculosis, syphilitic aortic aneurysm) ${ }^{40}$ Seventy-one percent of these benign etiologies are secondary to intravascular medical devices, as the most common cause. ${ }^{40}$

\section{Hypervolemia}

Hypervolemia, also known as fluid overload syndrome, is a condition where there is excessive fluid in the blood, primarily consisting of blood plasma, salt and water. Conditions associated with hypervolemia include heart failure, nephrotic syndrome, and liver disease, each of which has its own differentiating signs and symptoms. 
In the evaluation of hypervolemic heart failure patients, the physical examination has greater specificity and less sensitivity than the patient history. ${ }^{41}$ The most common general symptom is dyspnea (87-93\%), and exertional dyspnea is the most common type (86-97\%). ${ }^{41}$ Other more prevalent symptoms include edema (35-70\%), jugular vein distension (5-54\%), rales (25-45\%) and gallop heart beat (1-26\%). ${ }^{41}$

Nephrotic syndrome is a kidney disorder that is often idiopathic and characterized by peripheral edema, heavy proteinuria, hypoalbuminemia, and hyperlipidemia. ${ }^{42-44}$ Type 2 diabetes mellitus and systemic lupus erythematosus are the conditions that are most commonly associated with systemic causes of nephrotic syndrome. ${ }^{43,44} \mathrm{Clinical}$ signs include periorbital edema that is worse in the morning, end-of-day pitting edema of the legs, ${ }^{42}$ edema of the abdomen and genitals, ${ }^{42}$ foamy urine secondary to proteinuria, ${ }^{42}$ whitening of fingernails with or without white bands (Muercke's lines) secondary to severe hypoalbuminemia, ${ }^{42}$ and skin xanthomata secondary to elevated serum cholesterol. ${ }^{5}$ Some patients experience malaise. ${ }^{42}$ Diabetic nephrotic syndrome patients have the classic symptoms of weight loss, polyuria, polydipsia, and polyphagia. Systemic lupus erythematosus patients most commonly present with arthritis and/or arthralgia (86\%), butterfly rash (61\%) and anemia (55\%), followed by photosensitivity (48\%), fever (43\%), mouth ulcer (43\%), headache (36\%), the triad of fatigue, malaise, weakness (35\%), and alopecia (35\%).

Nephrotic syndrome associated with hepatic disease may produce non-specific symptoms of malaise or abdominal discomfort ${ }^{46}$. Although a pertinent medical history of alcoholism can assist the optometrist with a diagnosis of fatty liver disease, non-alcoholic patients are more difficult to diagnose, as most of these cases are detected incidentally through elevated liver enzymes on routine blood examination. ${ }^{46}$ Some patients may note an abdominal mass or a dorsocervical hump, which is associated with nonalcoholic steatohepatitis. ${ }^{47}$

\section{DIFFERENTIAL DIAGNOSIS}

Conjunctivochalasis and conjunctival lymphangiectasia can have features that mimic conjunctival chemosis.

Conjunctivochalasis is a bilateral aging condition in which redundant conjunctival tissue prolapses forward past the eyelid margin, possibly obstructing the lower punctae. ${ }^{63}$ Redundant conjunctiva is usually located temporally and centrally, a few millimeters below the lower limbus, ${ }^{64}$ while conjunctival chemosis extends to any quadrant. Mild cases of conjunctivochalasis are typically asymptomatic, while severe cases are more likely to result in punctal obstruction and tear film instability, with associated symptoms of foreign body sensation and epiphora. Such complications often result from mechanical disruption of the normal tear meniscus and impediment of nasolacrimal tear drainage. ${ }^{64}$

Conjunctival lymphangiectasia is a rare acquired condition that is characterized by unilateral or bilateral dilatation of the conjunctival blood vessels, usually temporarily. ${ }^{65}$ This condition represents secondary lymphedema caused by disruption or obstruction of the conjunctival lymphatic flow. ${ }^{65}$ It appears as diffuse enlargement of the conjunctival lymphatics (mimicking the appearance of chemosis) or focal dilatation of the lymphatics appearing as cysts. It is sometimes referred to as a "string of pearls" or "sausaging", ${ }^{6}$ depending on the presence or absence of blood. Although the condition is most often diagnosed by appearance, recurrent cases can be biopsied.$^{65}$ Anterior segment ocular coherence tomography (OCT) can be used by clinicians to forego biopsy and confirm the presence of dilated lymphatic vessels. ${ }^{66}$ Although the etiology is unknown, lymphangiectasia may be associated with previous trauma, other diseases (pterygium, neoplasm), or iatrogenic causes (ocular surgery, radiotherapy). ${ }^{65}$ Lymphangiectasia patients usually complain of epibulbar irregularities including injection, irritation, and epiphora ${ }^{65}$

\section{EXTERNAL EXAMINATION}

Suspicion of conjunctival chemosis as a result of a systemic condition requires physical evaluation of the patient, including the eyes and adnexa, head and neck, arms and legs, integument and hair, pulmonary system, and cardiovascular system. If a specific systemic association is suspected based upon a cursory examination, coordination of care with other specialties is important (Tables 4 and 5). 2,6,18,30-58

\section{Ocular Adnexa}

Cases of conjunctival chemosis accompanied by eyelid retraction and edema, scleral show, and proptosis are usually indicative of hyperthyroidism. Proptosis combined with conjunctival chemosis should prompt investigations for orbital cellulitis and cavernous sinus disease, especially with deficits noted on extraocular muscle and pupillary testing.

\section{Cardiovascular and Pulmonary Systems}

Vitals (temperature, weight, pulse, blood pressure) and auscultation of the heart and lungs can provide signs (gallop, rales, wheezing, stridor) that can assist with determining a systemic etiology of chemosis. 
Orbital cellulitis must be ruled out in patients who are febrile or have an oral temperature higher than $37.5^{\circ} \mathrm{C}\left(99.5^{\circ} \mathrm{F}\right)$. Orbital cellulitis may progress to develop signs of pain on eye movement, afferent pupillary defect, and periorbital edema.

Unintentional weight loss suggests hyperthyroidism or malignancy, while weight gain suggests hypervolemia. ${ }^{41}$ Tachycardia could suggest hyperthyroidism or heart failure, depending on the associated signs and symptoms. . $^{34,41}$ Gallop heart beat (a 3-4 beat heart sound) is heard in up to $26 \%$ of patients with heart failure, in addition to rales (crackling on inhalation) in $25-45 \%$ of patients. ${ }^{41}$

Hypotension (blood pressure less than $90 / 60 \mathrm{mmHg}$ ) and stridor (high-pitch whistling sound on inhalation) suggest a possible diagnosis of drug or food hypersensitivity. ${ }^{33}$

Dyspnea observed during external examination can be secondary to hypersensitivity reaction, hyperthyroidism, heart failure, superior vena cava syndrome, or various underlying hypervolemia etiologies. ${ }^{33,40,41,44}$ Assessing patients for Pemberton's sign, i.e., facial congestion and cyanosis when a patient elevates both arms, is specific for latent superior vena cava syndrome. ${ }^{67}$

\section{Head and Neck}

Assessing the patient's head and neck is crucial to rule out lymphadenopathy and jugular vein distension, as lymphoma, thyroid, bronchogenic carcinoma, tuberculosis, systemic lupus erythematosus and syphilitic aortic aneurysm can present with the former and cardiopulmonary disease can present with the latter - all of which can be associated with systemic causes of conjunctival chemosis.

\section{Integument and Hair}

An evaluation of the patient's integument for cutaneous manifestations such as alopecia (hair loss), rashes (changes in the skin's appearance, including changes in texture and/or color), and edema can help the practitioner determine systemic etiologies of conjunctival chemosis (Table 6). ${ }^{18,313,33,42,45,48,4,51,5,5,68-70}$

Hyperthyroidism, systemic lupus erythematosus, and secondary and tertiary syphilis can cause thin and brittle hair and/or hair loss (alopecia) of the scalp, eyebrow, and eyelashes. ${ }^{48,71}$

Jaundice may be seen in various systemic conditions, including liver disease, tuberculosis, histoplasmosis, syphilis, Hodgkin's and non-Hodgkin's lymphoma, cardiorenal syndrome, and systemic lupus erythematosus. ${ }^{51,71}$ Skin xanthomata are usually seen in nephrotic syndrome patients with hypercholesterolemia. ${ }^{42}$ Patients with white nails, with or without white bands (Muercke's lines), usually have underlying nephrotic syndrome. ${ }^{42}$ Skin rashes are more likely to be due to either a hypersensitivity reaction or systemic lupus erythematosus. Hypersensitivity reactions usually present with hives or urticaria, which appear as swollen, pale, red bumps or plaques. These reactions occur more often with foods than drugs $(85.9 \% \text { versus } 66.7 \%)^{33}$. Systemic lupus erythematosus rashes present as a malar, "butterfly" facial rash (61\%).

Unilaterality, type (pitting versus non-pitting), acuteness, and location of edema on external examination can assist with determining the etiology. Patients who sleep in a lateral decubitus position may have an ipsilateral presentation of interstitial fluid accumulation, whether in a limb (arm, leg) or the conjunctiva, on the side they sleep. ${ }^{52}$ Pitting edema, which is tissue indentation that remains after pressure is applied and released, may be observed in patients with heart failure, nephrotic syndrome, renal disease, and calcium channel blocker use. ${ }^{52}$ Non-pitting edema, which is tissue indentation that resolves after pressure is applied and released, may be observed in lymphoma, hyperthyroidism, and superior vena cava syndrome. ${ }^{52}$

Acute-onset edema forming in the deeper dermal layers, termed angioedema, is usually due to hypersensitivity reactions. It can occur in any location (i.e., face, tongue, larynx, abdomen, arms, and legs), and presents more often with hypersensitivity reactions to foods (23.2\%) than to drugs (18.1\%). ${ }^{33}$

Oral edema (lip-tongue-uvula edema) accompanied by skin itching and flushing is also usually due to hypersensitivity reactions, with a higher presence in foods than drugs hypersensitivities (90.9\% versus $69.4 \%) .{ }^{33}$

Periorbital edema usually presents in patients with carotid cavernous sinus thrombosis (80-100\%), hypersensitivity/allergy, hyperthyroidism, and nephrotic syndrome..$^{32}$ Nephrotic syndrome patients typically present with periorbital edema that is most noticeable in the morning, end-of-day pitting edema of the legs and abdomen, and endof-day edema of the genitals. ${ }^{42}$ 
Non-pitting pre-tibial myxedema is seen in $1-5 \%$ of Grave's disease patients. ${ }^{49,52}$ Although pre-malar and cheek swelling is seen in hyperthyroidism patients less than 50 years of age, its presentation is rare (1.84\%). ${ }^{39}$

Common edema noted in superior vena cava syndrome includes edema of the face or neck (82\%) and upper extremities $(68 \%)$, with the vast majority of these patients having bronchogenic carcinoma or the presence of an intravascular medical device..$^{40}$ The facial swelling in these lung cancer patients is prominent in the morning and resolves in the evening.

Generalized edema, anasarca, is seen in $35-70 \%$ of patients with hypervolemia. ${ }^{41}$ It is also seen in patients with hypersensitivity reactions, like the patient in this report who developed anasarca from amlodipine.

Abdominal edema is usually secondary to nephrotic syndrome or liver disease. ${ }^{43}$ Hepatic disease can present with abdominal, facial and peripheral edema.

Peripheral pitting edema of the arms and legs is usually due to hypervolemia (heart failure, nephrotic syndrome, liver disease). ${ }^{52}$

\section{TREATMENT AND MANAGEMENT}

Treatment depends on the etiology (bacterial, allergic, viral, inflammatory) and includes surgical procedures, removal of foreign bodies or eyelid cysts, and/or initiation of ophthalmic and oral antibiotics, anti-virals, anti-allergics, anti-inflammatories, and various oral and intravenous medications.

Management of conjunctival chemosis is determined by the course of the disease (i.e., acute, subacute, chronic), the etiology, and the urgency of implementing the treatment plan. Ocular etiologies usually require non-urgent coordination of care, unless the chemosis is secondary to sight-threatening ocular disorders (penetrating ocular foreign bodies, acute glaucoma, orbital cellulitis, scleral rupture, or endophthalmitis). When there is suspicion of scleral rupture or alkaline chemical burn, ophthalmology should be consulted immediately. Orbital cellulitis cases require immediate referral to the emergency department for evaluation, orbital computerized tonography with and without contrast, intravenous antibiotics, and consideration of an infectious disease referral. When all ocular etiologies are excluded, it is crucial to correlate the slit lamp biomicroscopy findings with patient history, symptoms, and external examination findings, to prevent unwarranted and expensive testing in search of systemic etiologies with a low yield (Table 3) ${ }^{16,1,2,2,28}$ Chemosis that is suspected to be due to carotid cavernous sinus thrombosis, carotid cavernous sinus fistula, or acute decompensated heart failure requires immediate, same-day, referral to the emergency department for evaluation, labs, and ancillary testing (Table 4), ${ }^{6,18,30-52}$ Non-emergent referrals to other specialties require coordination of care, so that the appropriate evaluation, labs, and ancillary testing can be completed to confirm or negate systemic conditions related to the eye-exam findings.

\section{CONCLUSION}

Conjunctival chemosis is frequently encountered in a primary eye care setting and exhibits a wide range of associations and severity. Although most cases have an ocular etiology, determined by history and examination, cases with systemic etiologies require a thorough history, review of symptomatology, physical examination (assessing for jugular vein distension, pitting and non-pitting edema, lymphadenopathy, rash, jaundice, and alopecia), and medical evaluation (pulse, BP, weight, heart and lung auscultation). In this report, two cases of conjunctival chemosis with different etiologies resulted in referrals to medical specialists to manage and treat their associated systemic conditions. 
Table 1: Ocular etiologies of conjunctival chemosis and corresponding mechanism of action ${ }^{2,5-19}$

\begin{tabular}{|c|c|c|c|}
\hline \multicolumn{2}{|c|}{ Etiology } & \multicolumn{2}{|l|}{ Chemosis Mechanism of Action } \\
\hline \multicolumn{2}{|c|}{$\begin{array}{l}\text { Ocular trauma } \\
\text { (including orbito-facial trauma) }\end{array}$} & $\begin{array}{l}\text { Acute cases: } \\
\text { Inflammatory reaction mediated by the release of } \\
\text { histamine, serotonin, and bradykinin, accompanied } \\
\text { by polymorphonuclear cell migration, which causes } \\
\text { arteriole dilation, an increased pressure gradient between } \\
\text { the arteriolar and venule capillaries, and extravasation of } \\
\text { intravascular fluid and resultant vasodilatory edema }\end{array}$ & $\begin{array}{l}\text { Chronic cases: } \\
\text { Blockage of } \\
\text { lymphatic system } \\
\text { from scarring or } \\
\text { damage to the } \\
\text { lymphatic drainage } \\
\text { system }^{19}\end{array}$ \\
\hline \multicolumn{2}{|l|}{ Ocular surgery $^{7}$} & \multicolumn{2}{|c|}{$\begin{array}{l}\text { Blockage of lymphatic system from scarring or damage to the lymphatic } \\
\text { drainage system }\end{array}$} \\
\hline $\begin{array}{l}\text { Anterior Segment } \\
\text { Infection }^{6}\end{array}$ & $\begin{array}{l}\text { Conjunctivitis; } \\
\text { Keratitis; Scleritis; } \\
\text { Endophthalmitis } \\
\text { (Bacterial or Viral) } \\
\end{array}$ & \multicolumn{2}{|c|}{$\begin{array}{l}\text { Arteriole dilation, an increased pressure gradient between the arteriolar } \\
\text { and venule capillaries, and extravasation of intravascular fluid and resultant } \\
\text { vasodilatory edema }^{18}\end{array}$} \\
\hline \multirow{3}{*}{$\begin{array}{l}\text { Anterior Segment } \\
\text { Inflammation }{ }^{6}\end{array}$} & $\begin{array}{l}\text { Seasonal or perennial } \\
\text { allergic conjunctivitis } \\
\text { or keratitis }^{6,12}\end{array}$ & \multicolumn{2}{|c|}{$\begin{array}{l}\text { Type I hypersensitivity (anaphylactoid) response, causing the release of } \\
\text { histamine, serotonin, and bradykinin, accompanied by polymorphonuclear } \\
\text { cell migration, which causes arteriole dilation, an increased pressure } \\
\text { gradient between the arteriolar and venule capillaries, and extravasation of } \\
\text { intravascular fluid and resultant vasodilatory edema }{ }^{2,18}\end{array}$} \\
\hline & $\begin{array}{l}\text { Medicamentosa } \\
\text { conjunctivitis or } \\
\text { keratitis }^{6,17}\end{array}$ & \multicolumn{2}{|c|}{$\begin{array}{l}\text { Type IV hypersensitivity (cell-mediated) response where CD4 T-helper cells } \\
\text { recognize an antigen and cause the release of interleukins, cytokines, and } \\
\text { enzymes, resulting in the extravasation of intravascular fluid and resultant } \\
\text { vasodilatory edema }\end{array}$} \\
\hline & $\begin{array}{l}\text { Episcleritis; Scleritis; } \\
\text { Uveitis }^{8}\end{array}$ & \multicolumn{2}{|c|}{$\begin{array}{l}\text { Arteriole dilation, an increased pressure gradient between the arteriolar } \\
\text { and venule capillaries, and extravasation of intravascular fluid and resultant } \\
\text { vasodilatory edema }^{5}\end{array}$} \\
\hline \multicolumn{2}{|l|}{ Acute Glaucoma $^{23}$} & \multicolumn{2}{|l|}{ Numerous mechanisms depending on the etiology } \\
\hline \multirow{2}{*}{ Orbital Disease $^{9}$} & $\begin{array}{l}\text { Orbital infection } \\
{\text { (cellulitis) })^{13}}\end{array}$ & \multicolumn{2}{|c|}{$\begin{array}{l}\text { Sinus or upper respiratory infection spreading to the orbit and causing } \\
\text { infection and inflammation of ocular tissues posterior to the orbital septum }\end{array}$} \\
\hline & $\begin{array}{l}\text { Orbital pseudotumor } \\
\text { or malignancy }^{11}\end{array}$ & \multicolumn{2}{|l|}{ Congestion or blockage of the lymphatic or venous system ${ }^{11}$} \\
\hline
\end{tabular}


Table 2: Chemosis inducing ocular and systemic medications ${ }^{16-18,21-27}$

\begin{tabular}{|c|c|c|}
\hline & Ocular Medications & Systemic Medications \\
\hline Topical anesthetics & \begin{tabular}{|l} 
Proparacaine, ${ }^{17}$ \\
Tetracaine, ${ }^{17}$ \\
Lidocaine, $^{17}$ \\
Benoxinate, $^{17}$ \\
NSAIDS $^{17}$
\end{tabular} & Birth control pills ${ }^{23}$ \\
\hline Cycloplegics & Homatropine, Atropine $e^{17,18}$ & Hormone replacement ${ }^{23}$ \\
\hline Glaucoma medications & $\begin{array}{l}\text { Apraclonidine, }{ }^{17} \\
\text { Brimonidine, }{ }^{17} \\
\text { Dorzolamide, }{ }^{17} \\
\text { Prostaglandin analogues, }{ }^{17,18} \\
\text { Dipivalyl epinephrine, }{ }^{18} \\
\text { Echothiophate, }^{18} \text { Pilocarpine }^{18} \\
\end{array}$ & Anti-depressants ${ }^{23}$ \\
\hline Antivirals & \begin{tabular}{|l} 
Idoxuridine, $^{18}$ \\
Vidaribine, $^{18}$ \\
Trifluoridine $^{18}$
\end{tabular} & NSAID (ketoprofen; diclofenac) ) $^{23,25}$ \\
\hline Aminoglycosides & $\begin{array}{l}\text { Tobramycin, }{ }^{18} \\
\text { Gentamycin, } \\
\text { Neomycin }^{18} \\
\text { Vancomycin }^{18}\end{array}$ & Imatinib mesylate (Gleevac) ${ }^{24}$ \\
\hline Artificial tears & Lanolin-based artificial tears ${ }^{16}$ & \multirow{2}{*}{$\begin{array}{l}\text { Hypertensive medications }{ }^{23,26,27} \\
\text { (Calcium channel blockers like amlodipine) }\end{array}$} \\
\hline $\begin{array}{l}\text { Preservatives in } \\
\text { ophthalmic medications }\end{array}$ & $\begin{array}{l}\text { Benzalkonium chloride; } \\
\text { phenylmercuric } \text { nitrate }^{17,18,22}\end{array}$ & \\
\hline
\end{tabular}

Table 3: Ocular Signs of Medicamentosa ${ }^{16,17,21,28}$

\begin{tabular}{|c|c|c|}
\hline Eyelid & Conjunctiva & Cornea \\
\hline Punctal stenosis ${ }^{21,28}$ & Follicular or papillary reaction ${ }^{21,28}$ & Superficial punctate epitheliopathy $y^{21,28}$ \\
\hline \multirow{6}{*}{ Eyelid \&/or periorbital swelling ${ }^{17,21}$} & Bulbar injection ${ }^{17,21}$ & Epithelial defect, ulceration ${ }^{16,21}$ \\
\hline & Symblepharon \&/or fornix shortening ${ }^{17,21}$ & Ulceration $^{16,28}$ \\
\hline & \multirow{4}{*}{ Scarring ${ }^{21,28}$} & Scarring $^{16}$ \\
\hline & & Pannus ${ }^{16}$ \\
\hline & & Neovascularization $^{16}$ \\
\hline & & Perforation $^{16}$ \\
\hline
\end{tabular}


Table 4a: Conjunctival chemosis with a systemic etiology of Hypersensitivity/Allergy

\begin{tabular}{|c|c|c|c|c|}
\hline Association & Presentation & Symptomology & Work-Up & $\begin{array}{l}\text { Coordination of } \\
\text { Care Specialist }\end{array}$ \\
\hline Food & \multirow[t]{2}{*}{ Acute } & $\begin{array}{l}\text { Skin itching, flushing, eye, lip-tongue- } \\
\text { uvula edema (90.9\%), Urticaria } \\
\text { (86.9\%), Cardiovascular symptoms } \\
\text { such as syncope, hypotension, urinary } \\
\text { incontinence, chest discomfort ( } 31.3 \%) \text {, } \\
\text { Hypotension (26.3\%), Respiratory } \\
\text { symptoms such as wheezing, stridor, } \\
\text { hypoxemia (49.5\%), Dyspnea (47.5\%), } \\
\text { Gastrointestinal symptoms such as } \\
\text { crampy abdominal pain, vomiting, } \\
\text { diarrhea (24.2\%), Angioedema (23.2\%), } \\
\text { Pruritis (27.3\%), and Neurological } \\
(20.2 \%)^{33}\end{array}$ & \multirow[t]{2}{*}{$\begin{array}{l}\text { Skin prick test and } \\
\text { serum allergen } \\
\text { specific IgE } \\
\text { tests (multiple } \\
\text { allergosorbent } \\
\text { test, MAST), CBC } \\
\text { with differential, } \\
\text { Serum total } \\
\text { IgE, Eosinophil } \\
\text { cationic protein } \\
\text { (ECP), Liver } \\
\text { panel }^{33}\end{array}$} & \multirow[t]{2}{*}{$\begin{array}{l}\text { Allergist or } \\
\text { Emergency } \\
\text { Department } \\
\text { depending on the } \\
\text { severity }\end{array}$} \\
\hline Drug & & $\begin{array}{l}\text { Skin itching, flushing, eye, lip-tongue- } \\
\text { uvula edema(69.4\%), Urticaria(66.7\%), } \\
\text { Cardiovascular symptoms such } \\
\text { as syncope, hypotension, urinary } \\
\text { incontinence, chest discomfort( } 63.9 \%) \text {, } \\
\text { Hypotension (41.7\%), Respiratory } \\
\text { symptoms such as wheezing, stridor, } \\
\text { hypoxemia (45.8\%), Dyspnea (45.8\%), } \\
\text { Gastrointestinal symptoms such as } \\
\text { crampy abdominal pain, vomiting, } \\
\text { diarrhea (25\%), Angioedema (18.1\%), } \\
\text { Pruritis (23.6\%), and Neurological } \\
(26.4 \%)^{33}\end{array}$ & & \\
\hline
\end{tabular}

Table 4b: Conjunctival chemosis with a systemic etiology of Cavernous Sinus Disease

\begin{tabular}{|c|c|c|c|c|}
\hline & Presentation & Symptomology & Work-Up & $\begin{array}{l}\text { Coordination of } \\
\text { Care Specialist }\end{array}$ \\
\hline $\begin{array}{l}\text { Carotid cavernous } \\
\text { sinus fistula }\end{array}$ & Subacute or Chronic & $\begin{array}{l}\text { Corkscrew arterialization } \\
\text { of conjunctival veins } \\
(93 \%) \text {, Proptosis }(84 \%) \text {, } \\
\text { Decreased visual acuity } \\
(43 \%) \text {, Chemosis ( } 42 \%) \text {, } \\
\text { Ophthalmoparesis ( } 52 \%: 73 \% \\
\text { abducens, } 5 \% \text { oculomotor, } \\
22 \% \text { multiple), and Ocular } \\
\text { bruit }(28 \%)^{30}\end{array}$ & $\begin{array}{l}\text { CT/CTA, or MRI/ } \\
\text { MRA, or PCVD }{ }^{47}\end{array}$ & $\begin{array}{l}\text { Emergency } \\
\text { Department }\end{array}$ \\
\hline $\begin{array}{l}\text { Carotid cavernous } \\
\text { sinus thrombosis }\end{array}$ & Acute & $\begin{array}{l}\text { Fever, proptosis, ptosis, CN } \\
\text { III,IV or VI palsy (80-100\%), } \\
\text { Periorbital edema, headache, } \\
\text { lethargy, altered sensorium } \\
\text { (50-80\%), Optic disc edema, } \\
\text { and Venous engorgement }{ }^{32}\end{array}$ & $\begin{array}{l}\text { CT/CTA or MRI/ } \\
\text { MRA }^{58}\end{array}$ & $\begin{array}{l}\text { Emergency } \\
\text { Department }\end{array}$ \\
\hline
\end{tabular}


Table 4c: Conjunctival chemosis with a systemic etiology of Thyroid Disease (Hyperthyroidism1)

\begin{tabular}{|c|c|c|c|}
\hline Presentation & Symptomology & Work-Up & $\begin{array}{l}\text { Coordination of } \\
\text { Care Specialist }\end{array}$ \\
\hline \multirow[t]{3}{*}{$\begin{array}{l}\text { Subacute/ } \\
\text { Chronic }\end{array}$} & $\begin{array}{l}\text { Older patients (> 70y) }{ }^{34} \\
\text { Tachycardia (71\%), Fatigue (56\%), Weight Loss (50\%), } \\
\text { Tremor (44\%), Dyspnea (41\%), Apathy (41\%), Anorexia } \\
\text { (32\%), Nervousness (31\%), Hyperactive reflexes ( } 28 \%) \text {, } \\
\text { Weakness (27\%) Depression (24\%), and Increased sweating } \\
(24 \%),{ }^{34} \text { Alopecia, }{ }^{31} \text { Non-pitting pretibial myxedema }{ }^{31,52}\end{array}$ & \multirow{3}{*}{$\begin{array}{l}\text { Skin prick test and } \\
\text { serum allergen } \\
\text { specific IgE } \\
\text { tests (multiple } \\
\text { allergosorbent } \\
\text { test, MAST), CBC } \\
\text { with differential, } \\
\text { Serum total IgE, } \\
\text { Eosinophil cationic } \\
\text { protein (ECP), } \\
\text { Liver panel }^{33}\end{array}$} & \multirow[t]{3}{*}{$\begin{array}{l}\text { Allergist or } \\
\text { Emergency } \\
\text { Department } \\
\text { depending on the } \\
\text { severity }\end{array}$} \\
\hline & $\begin{array}{l}\text { Younger patients }(<50 y)^{34} \\
\text { Tachycardia }(96 \%), \text { Hyperactive reflexes (96\%), Increased } \\
\text { sweating (95\%), Heat intolerance (92\%), Fatigue (84\%), } \\
\text { Nervousness (84\%), Tremor (84\%), Polydipsia (67\%), } \\
\text { Weakness (61\%), Increased appetite (57\%), Dyspnea (56\%), } \\
\text { Weight Loss (51\%), Diarrhea (43\%), Anorexia (32\%), Apathy } \\
(25 \%) \text {, and Depression (22\%), }{ }^{34} \text { Alopecia, }{ }^{31} \text { Non-pitting pre- } \\
\text { tibial edema (1-5\%) }\end{array}$ & & \\
\hline & $\begin{array}{l}\text { Thyroid orbitopathy(25-40\%) })^{35,36} \\
\text { Eyelid retraction (90.7\% at some point in the disease; } 70 \% \\
\text { at time of diagnosis), Exophthalmos( } 62 \%) \text {, Restrictive } \\
\text { extraocular myopathy ( } 43 \%) \text {, Optic nerve dysfunction } \\
\text { (6\%), Full constellation of manifestations including } \\
\text { eyelid retraction, exophthalmos, optic nerve dysfunction, } \\
\text { extraocular muscle involvement (5\%), Pain (30\%), } \\
\text { Lacrimation ( } 20.8 \%) \text {, Diplopia ( } 16.6 \% \text { at initial presentation) } \\
\text {, Photophobia (15.8\%), Blurred vision (7.5\%), Thyroid } \\
\text { dermopathy (4\%), and Acropachy(1\%), }{ }^{37} \text { Glabellar rhytids } \\
\text { (82.5\%),38 Premalar and cheek swelling(1.84\%), }{ }^{39} \text { Non-pitting } \\
\text { pre-tibial edema (1-5\%), }{ }^{49} \text { Alopecia }{ }^{31}\end{array}$ & & \\
\hline
\end{tabular}

Table 4d: Conjunctival chemosis with a systemic etiology of Superior Vena Cava Syndrome

\begin{tabular}{|c|c|c|c|c|}
\hline & Presentation & Symptomology & Work-Up & $\begin{array}{l}\text { Coordination of } \\
\text { Care Specialist }\end{array}$ \\
\hline $\begin{array}{l}\text { Malignant causes }(60 \%)^{40} \\
\text { Lymphoma }(8 \%)^{40} \\
\text { Bronchogenic Carcinoma }(46 \%)^{40} \\
\text { - Small cell lung cancer }(22 \%)^{40} \\
\text { - Non-small cell lung cancer }(24 \%)^{40} \\
\text { Germ Cell Tumor }(8 \%)^{40} \\
\text { - Metastatic prostate cancer }(1.2 \%)^{40} \\
\text { - Thymic cancer }(1.2 \%)^{40} \\
\text { - Adenocarcinoma of unknown site }(1.2 \%)^{40}\end{array}$ & $\begin{array}{l}\text { Subacute/ } \\
\text { Chronic }\end{array}$ & \multirow{4}{*}{$\begin{array}{l}\text { SVC generalized } \\
\text { symptoms: Facial or } \\
\text { Neck swelling (82\%), } \\
\text { Upper extremity } \\
\text { swelling ( } 68 \%), \text { Dyspnea } \\
\text { (66\%), Cough (50\%), } \\
\text { and Dilated chest vein } \\
\text { collaterals (38\%), } \\
\text { Jaundice in lymphoma } \\
\text { and syphillis }\end{array}$} & \multirow{4}{*}{$\begin{array}{l}\text { CT or MRI } \\
\text { chest at initial } \\
\text { evaluation } \\
\text { and tissue } \\
\text { biopsy of } \\
\text { masses }^{52}\end{array}$} & Oncologist \\
\hline $\begin{array}{l}\text { Benign Causes(40\%) })^{40} \\
\text { Intravascular device (71\%), dialysis catheters }\end{array}$ & \multirow{3}{*}{$\begin{array}{l}\text { Subacute/ } \\
\text { Chronic }\end{array}$} & & & Cardiologist \\
\hline Fibrosing mediastinitis $(8 \%)^{40}$ & & & & $\begin{array}{l}\text { Infectious } \\
\text { Disease; } \\
\text { Cardiologist }\end{array}$ \\
\hline $\begin{array}{l}\text { - Lymphoma, Histoplasmosis, Tuberculous, } \\
\text { and Syphilitic aortic aneurysms }{ }^{40} \\
\text { Other }(3.6 \%)^{40} \\
\text { - Hematoma after aortic dissection repair; } \\
\text { Pseudo- tumor; Primary SVC thrombosis }{ }^{40}\end{array}$ & & & & Cardiologist \\
\hline
\end{tabular}


Table 4e: Conjunctival chemosis with a systemic etiology of Hypervolemia

\begin{tabular}{|c|c|c|c|c|}
\hline & Presentation & Symptomology & Work-Up & $\begin{array}{l}\text { Coordination of } \\
\text { Care Specialist }\end{array}$ \\
\hline Cardiopulmonary Failure & $\begin{array}{l}\text { Subacute/ } \\
\text { Chronic }\end{array}$ & $\begin{array}{l}\text { All forms of Dyspnea, (87- } \\
\text { 93\%), Exertional dyspnea } \\
\text { (86-97\%), Orthopnea(10-59\%), } \\
\text { Paroxysmal dyspnea(13-39\%), } \\
\text { Dyspnea at rest(1-6\%), Weight } \\
\text { gain (5-15\%), Jugular vein } \\
\text { distension (5-54\%), Abdominal } \\
\text { jugular reflex (6\%), Edema } \\
\text { (35-70\%), Gallop heart beat } \\
\text { (1-26\%), Rales (25-45\%), and } \\
\text { Ascites (3-17\%).41 Jaundice if } \\
\text { cardiorenal failure51 }\end{array}$ & $\begin{array}{l}\text { Hematocrit, protein } \\
\text { level, albumin level, } \\
\text { creatinine level, blood } \\
\text { urea nitrogen level, } \\
\text { plasma osmolality, and } \\
\text { urine- specific gravity, } \\
\text { Chest radiography, } \\
\text { pulmonary artery } \\
\text { catheterization, PRO } \\
\text { BNP, CORS, TTE }\end{array}$ & $\begin{array}{l}\text { Cardiologist; } \\
\text { Emergency } \\
\text { Department }\end{array}$ \\
\hline \multirow[t]{3}{*}{$\begin{array}{l}\text { Nephrotic Syndrome } \\
\text { Idiopathic (80-90\%) })^{43,44} \\
\text { Primary Kidney Disease } \\
(10 \%)^{43,44} \\
\text { Membranous Nephropathy } \\
\text { (30-35\%), Focal Segmental } \\
\text { Glomerulosclerosis } \\
\text { (30-35\%), Minimal } \\
\text { Change Disease (15\%), } \\
\text { and Immunoglobulin A } \\
\text { nephropathy (15\%) }{ }^{43,44}\end{array}$} & \multirow[t]{3}{*}{$\begin{array}{l}\text { Subacute/ } \\
\text { Chronic }\end{array}$} & $\begin{array}{l}\text { General symptoms for } \\
\text { primary and secondary } \\
\text { disease: Malaise, Weight gain, } \\
\text { Foamy urine, Morning time } \\
\text { periorbital edema, white } \\
\text { nails with or without white } \\
\text { bands (Muercke's lines), skin } \\
\text { xanthomata, and Alopecia } \\
\text { Significant evening peripheral } \\
\text { pitting edema }{ }^{31,42} \\
\text { Jaundice }^{51}\end{array}$ & \multirow{3}{*}{$\begin{array}{l}\text { Urinalysis with protein } \\
\text { to creatinine ratio, } \\
\text { CBC and coagulation } \\
\text { panel, renal function } \\
\text { electrolytes, liver } \\
\text { panel, glucose and } \\
\text { HbAlC, focused } \\
\text { testing for disorders } \\
\text { by history and physical } \\
\text { examination } \\
\text { ANA, Anti-dsDNA AB, } \\
\text { anti-Sm AB, Anti- } \\
\text { phospholipid AB, anti- } \\
\text { RNA AB }{ }^{22,43}\end{array}$} & \multirow[t]{3}{*}{$\begin{array}{l}\text { Nephrologist; } \\
\text { Rheumatologist }\end{array}$} \\
\hline & & $\begin{array}{l}\text { Weight loss, polyuria, } \\
\text { polydipsia, polyphagia }\end{array}$ & & \\
\hline & & $\begin{array}{l}\text { Systemic lupus erythematosus: } \\
\text { Arthritis and/or arthralgia } \\
(86 \%) \text {, butterfly rash } \\
(61 \%) \text {, anemia ( } 55 \%) \text {, } \\
\text { photosensitivity( } 48 \%) \text {, fever } \\
\text { ( } 43 \%) \text {, mouth ulcer ( } 43 \%) \text {, } \\
\text { headache ( } 36 \%) \text {, fatigue, } \\
\text { malaise, and weakness ( } 35 \%) \text {, } \\
\text { and alopecia( } 35 \%)^{45} \\
\text { Non-pitting, generalized } \\
\text { edema,. } \\
\text { Dependent pitting edema at the } \\
\text { end of the day }{ }^{18}\end{array}$ & & \\
\hline Renal Disease & $\begin{array}{l}\text { Subacute/ } \\
\text { Chronic }\end{array}$ & $\begin{array}{l}\text { Malaise or abdominal } \\
\text { discomfort, }{ }^{46} \text { abdominal mass, }{ }^{46} \\
\text { or a dorsocervical hump, }{ }^{47} \\
\text { jaundice, }{ }^{51} \text { weight gain, }{ }^{41} \text { Facial } \\
\text { edema, Abdominal edema, } \\
\text { Peripheral pitting edema }{ }^{52}\end{array}$ & 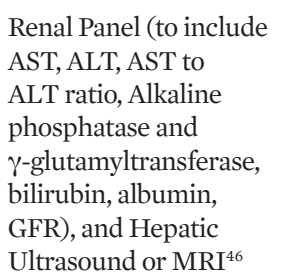 & Hepatologist \\
\hline
\end{tabular}


Table 5: Conjunctival chemosis mechanism of action of systemic disorder ${ }^{2,6,18,33,40,42,49,53-58}$

\begin{tabular}{|c|c|c|c|}
\hline Etiology & \multicolumn{3}{|r|}{ Systemic Mechanism of Action } \\
\hline \multirow[t]{2}{*}{$\begin{array}{l}\text { Cavernous Sinus } \\
\text { Disease }\end{array}$} & \multicolumn{2}{|c|}{ Carotid cavernous sinus fistula } & 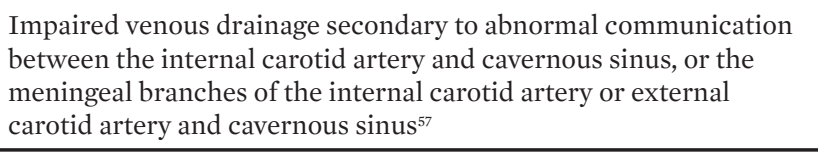 \\
\hline & \multicolumn{2}{|c|}{ Carotid cavernous sinus thrombosis } & $\begin{array}{l}\text { Impaired venous drainage secondary to nasal, sinus, ear, or dental } \\
\text { infection }\end{array}$ \\
\hline \multicolumn{3}{|c|}{ Hypersensitivity/ Allergy } & $\begin{array}{l}\text { Allergic reaction to animal dander, pollen, food, medication, venom } \\
\text { or drugs, mediated by the release of histamine, serotonin, and } \\
\text { bradykinin, accompanied by polymorphonuclear cell migration, } \\
\text { which causes arteriole dilation, an increased pressure gradient } \\
\text { between the arteriolar and venule capillaries, and extravasation of } \\
\text { intravascular fluid and resultant vasodilatory edema', }{ }^{2,8,33}\end{array}$ \\
\hline \multicolumn{3}{|l|}{ Hyperthyroidism } & $\begin{array}{l}\text { Fluid accumulation of glycosaminoglycans in connective tissue, } \\
\text { resulting in edema and inflammation of the extraocular muscles, } \\
\text { orbital connective tissue and fat, increased orbital volume, and } \\
\text { decreased venous and lymphatic drainage }{ }^{49,53}\end{array}$ \\
\hline \multirow{6}{*}{$\begin{array}{l}\text { Superior Vena } \\
\text { Cava Syndrome }\end{array}$} & \multicolumn{2}{|l|}{ Lymphoma } & $\begin{array}{l}\text { Large lymph node compressing the superior vena cava causing } \\
\text { decreased venous drainage }{ }^{40}\end{array}$ \\
\hline & \multicolumn{2}{|c|}{$\begin{array}{l}\text { Bronchogenic. Carcinoma (Small } \\
\text { and Non-Small Lung Cancer) }\end{array}$} & $\begin{array}{l}\text { Mass compressing the superior vena cava causing decreased } \\
\text { venous drainage }{ }^{40}\end{array}$ \\
\hline & \multicolumn{2}{|c|}{$\begin{array}{l}\text { Germ Cell Tumor (Prostate, } \\
\text { Thymic, Adenocarcinoma) }\end{array}$} & $\begin{array}{l}\text { Mass compressing the superior vena cava causing decreased } \\
\text { venous drainage }{ }^{40}\end{array}$ \\
\hline & \multicolumn{2}{|c|}{ Intravascular devices } & $\begin{array}{l}\text { Device compressing the superior vena cava causing decreased } \\
\text { venous drainage } \mathrm{e}^{40}\end{array}$ \\
\hline & \multicolumn{2}{|c|}{$\begin{array}{l}\text { Fibrosing mediastinitis (Lymphoma; } \\
\text { Histoplasmosis; Tuberculosis; } \\
\text { Syphilic aortic aneurysm) }\end{array}$} & $\begin{array}{l}\text { Fibrous tissue scarring compressing the superior vena cava causing } \\
\text { decreased venous drainage }{ }^{40}\end{array}$ \\
\hline & \multicolumn{2}{|c|}{$\begin{array}{l}\text { Other (Hematoma after aortic } \\
\text { dissection repair; Pseudo- tumor; } \\
\text { Primary SVC thrombosis) }\end{array}$} & $\begin{array}{l}\text { Compression of the superior vena cava causing decreased venous } \\
\text { drainage }^{40}\end{array}$ \\
\hline \multirow{5}{*}{$\begin{array}{l}\text { Fluid Overload } \\
\text { Syndrome }\end{array}$} & \multicolumn{2}{|c|}{ Cardiopulmonary Failure } & $\begin{array}{l}\text { Dilatation of the ocular vascular system caused by hypoxia, } \\
\text { hypercapnia, which impedes thoracic venous return, by positive } \\
\text { pressure ventilation, inducing jugular venous distention and fluid } \\
\text { overload }^{56}\end{array}$ \\
\hline & \multirow{3}{*}{$\begin{array}{l}\text { Nephrotic } \\
\text { Syndrome }\end{array}$} & $\begin{array}{l}\text { Primary Kidney } \\
\text { Disease }\end{array}$ & $\begin{array}{l}\text { Low blood protein (hypoproteinemia), causing decreased colloidal } \\
\text { osmotic pressure, which alters the osmotic gradient between the } \\
\text { plasma and interstitial fluid, causing salt and water retention, and fluid } \\
\text { egression into extracellular spaces }{ }^{6,42,54}\end{array}$ \\
\hline & & & \multirow{2}{*}{$\begin{array}{l}\text { Patients with systemic signs: Low blood protein (hypoproteinemia), } \\
\text { causing decreased colloidal osmotic pressure, which alters the osmotic } \\
\text { gradient between the plasma and interstitial fluid, causing fluid } \\
\text { egression into extracellular spaces } \\
\text { Patients without systemic signs: Localized edema from immune } \\
\text { complexes, causing increased polymorphonuclear cell presence, and } \\
\text { increased edema and inflammation }{ }^{5,55}\end{array}$} \\
\hline & & $\begin{array}{l}\text { Secondary } \\
\text { Kidney Disease, } \\
\text { specifically } \\
\text { Systemic Lupus } \\
\text { Erythematosus }\end{array}$ & \\
\hline & \multicolumn{2}{|l|}{ Liver Disease } & $\begin{array}{l}\text { Low blood protein (hypoalbuminemia) causing decreased colloidal } \\
\text { osmotic pressure, an increase in oncotic pressure, and fluid egression } \\
\text { into the ocular soft tissues }\end{array}$ \\
\hline
\end{tabular}


Table 6: Cutaneous presentations in systemic diseases that may present with conjunctival chemosis ${ }^{18,31,33,42,45,48,49,51,52,68-70}$

\begin{tabular}{|c|c|c|c|c|c|c|}
\hline \multirow{2}{*}{\multicolumn{2}{|c|}{ Systemic Condition }} & \multicolumn{5}{|c|}{ Cutaneous Presentation } \\
\hline & & Rash & $\begin{array}{c}\text { Alopecia } \\
\text { (Yes Or No) }\end{array}$ & $\begin{array}{c}\text { Jaundice } \\
\text { (Yes Or No) }\end{array}$ & \multicolumn{2}{|c|}{$\begin{array}{c}\text { Edema } \\
\text { (None; Pitting; } \\
\text { Non-Pitting) }\end{array}$} \\
\hline \multirow[t]{2}{*}{$\begin{array}{l}\text { Hypersensitivity/ } \\
\text { Allergy }\end{array}$} & Drug-induced & $\begin{array}{l}\text { Hives; Urticaria (swollen, } \\
\text { pale, red bumps or } \\
\text { plaques) } 66.7 \%^{33}\end{array}$ & No & No & \multicolumn{2}{|l|}{ None } \\
\hline & Food-induced & $\begin{array}{l}\text { Hives; Urticaria (swollen, } \\
\text { pale, red bumps or } \\
\text { plaques); } 86.9 \%^{33}\end{array}$ & No & No & \multicolumn{2}{|l|}{ None } \\
\hline \multicolumn{2}{|c|}{ Hyperthyroidism/Grave's Disease } & $\begin{array}{l}\text { Pretibial myxedema } \\
\text { presenting with } \\
\text { asymptomatic warm, } \\
\text { moist, soft, velvety, and } \\
\text { smooth erythema to the } \\
\text { severe elephantiasic } \\
\text { form }(1-5 \%)^{49,52}\end{array}$ & Yes $^{10}$ & No & \multicolumn{2}{|c|}{$\begin{array}{l}\text { Non-pitting pretibial } \\
\text { myxedema }^{31,52}\end{array}$} \\
\hline $\begin{array}{l}\text { Superior Vena } \\
\text { Cava Syndrome }\end{array}$ & $\begin{array}{l}\text { Tumor, Lymph } \\
\text { node, lymphatic } \\
\text { vessel damage, } \\
\text { radiotherapy }\end{array}$ & No & No & $\begin{array}{l}\text { Yes, if } \\
\text { lymphoma }^{51}\end{array}$ & \multicolumn{2}{|c|}{ Non-Pitting ${ }^{52}$} \\
\hline \multirow[t]{3}{*}{$\begin{array}{l}\text { Syphilis } \\
\text { (presenting in } \\
\text { extragenital } \\
\text { areas) }\end{array}$} & Primary & $\begin{array}{l}\text { Chancre without } \\
\text { basal induration with } \\
\text { edges rising above the } \\
\text { surrounding surface }(2 \%)^{69}\end{array}$ & \multirow[t]{3}{*}{ Yes } & \multirow[t]{3}{*}{ Yes $^{51}$} & \multirow{2}{*}{\multicolumn{2}{|c|}{ None }} \\
\hline & Secondary & $\begin{array}{l}\text { Macular, popular, } \\
\text { papulosquamous, } \\
\text { pustular lesion ( } 4.76 \%- \\
59 \%) \text {, depending on } \\
\text { location, with higher } \\
\text { presentation on soles, } \\
\text { trunk, arms, palms, legs. }{ }^{70}\end{array}$ & & & & \\
\hline & Tertiary & $\begin{array}{l}\text { Firm necrotic centered } \\
\text { gummi lesions }(15 \%)^{48}\end{array}$ & & & \multicolumn{2}{|c|}{$\begin{array}{l}\text { Pitting, if patient has } \\
\text { heart failure }{ }^{52}\end{array}$} \\
\hline \multirow[t]{4}{*}{$\begin{array}{l}\text { Fluid Overload } \\
\text { Syndrome }\end{array}$} & $\begin{array}{l}\text { Congestive } \\
\text { Heart Failure }\end{array}$ & No & No & $\begin{array}{l}\text { Yes, if } \\
\text { cardiorenal } \\
\text { failure }^{51}\end{array}$ & Pitting ${ }^{51}$ & \\
\hline & \multirow[t]{2}{*}{$\begin{array}{l}\text { Nephrotic } \\
\text { Syndrome }\end{array}$} & Primary Kidney disease & $\begin{array}{l}\text { White nails } \\
\text { with or without } \\
\text { white bands } \\
\text { (Muercke's } \\
\text { lines), and skin } \\
\text { xanthomata }^{22}\end{array}$ & \multirow[t]{2}{*}{ Yes $^{48}$} & \multirow[t]{2}{*}{ Yes $^{51}$} & \multirow{2}{*}{$\begin{array}{l}\text { Non- } \\
\text { pitting } \\
\text { generalized } \\
\text { edema }^{18,52} \\
\text { or } \\
\text { dependent } \\
\text { pitting } \\
\text { edema at } \\
\text { the end of } \\
\text { the day }{ }^{18}\end{array}$} \\
\hline & & $\begin{array}{l}\text { Systemic Lupus } \\
\text { Erythematosus }\end{array}$ & $\begin{array}{l}\text { White nails } \\
\text { with or without } \\
\text { white bands } \\
\text { (Muercke's } \\
\text { lines), and skin } \\
\text { xanthomata }{ }^{42} \\
\text { Any form of } \\
\text { rash (>80\%) } \\
\text { Butterfly rash } \\
(61 \%)^{45}\end{array}$ & & & \\
\hline & Renal Disease & & No & Yes $^{51}$ & Pitting $^{52}$ & \\
\hline
\end{tabular}




\section{REFERENCES}

1. Hunter PA. The conjunctiva: diseases and tumours. In: Spalton DJ, Hitchings RA, Hunter PA, eds. Atlas of Clinical Ophthalmology, 2nd edn. London: , 1998:3-5.

2. Kanski JJ, Bowling B. Clinical CITY OF PUBLICATION: PUBLISHER, YEAR OF PUBLICATION:131-66.

3. Dutton J. Atlas of Clinical and Surgical Orbital Anatomy, 2nd edn. CITY OF PUBLICATION: PUBLISHER, 2011:129-64.

4. Remington L. Clinical Anatomy of the Visual System. Boston: Butterworth-Heinemann, 1998:137-56.

5. Minckler MR, Newell C, Drummond B. Chemosis from trauma. West J Emerg Med 2014;15(4):357-8.

6. Kalin NS, Orlin SE, Wulc AE, et al. Chronic localized conjunctival chemosis. Cornea 1996; 15(3):295-300.

7. Weinfeld AB, Burke R, Codner MA. The comprehensive management of chemosis following cosmetic lower blepharoplasty. Plast Reconstr Surg 2008;122:579-86.

8. Kim HK, Kim WS. Chronic unilateral chemosis following the use of amlodipine besylate. BMC Ophthalmol 2014;14:124.

9. Gans H, Sekula J, Wlodyka J. Treatment of acute orbital complications. Arch Otolaryngol 1974;100:329-32.

10. Cioffi GA, Van Buskirk EM. Clinical manifestations of the glaucomas. In: Wright KW, ed. Textbook of Ophthalmology. Baltimore, MD: , 1997:597-624.

11. Medeiros LJ, Harmon DJ, Lingood RM, Harris NL. Immunohistologic features predict clinical behavior of orbital and conjunctival lymphoid infiltrates. Blood 1989; 74:2121-9.

12. Schroder K, Finis D, Meller S, Buhren BA, Wagenmann M, Geerling G. Seasonal and perennial allergic rhinoconjunctivitis. Laryngorhinootologie 2017; 96(2):89-97.

13. Allegrini D, Reposi S, Nocerino E, Pece A. Odontogenic orbital cellulitis associated with cavernous sinus thrombosis and pulmonary embolism: a case report. J Med Case Rep 2017 Jun 20;11(1):16414. Michael KB, Rotchford A, Ramaesh K. Conjunctival chemosis as a specific feature of pseudomonas aeruginosa corneal ulcers. Cornea 2016;35:1182-4.

15. Murthy SI, Sati A, Sangwan V. Infectious scleritis mimicking severe ocular inflammation: atypical initial presentation. BMJ Case Rep 2013 Feb 20;2013.

16. Graue-Hernández EO, Navas A, Ramírez-Miranda A. Toxic keratoconjunctivitis. In: Holland EJ, Mannis MJ, Lee WB, eds. Ocular Surface Disease: Cornea, Conjunctiva and Tear Film. London: W.B. Saunders, 2013:189-93.

17. Paley GL, Lubniewski AJ, Reidy JJ, Farooq AV. Toxic keratoconjunctivitis. Eye Contact Lens 2018 Sep;44 Suppl 1:S8-S15.18. Liesegang TJ. Conjunctiva. In: Wright KW, ed. Textbook of Ophthalmology. Baltimore, MD: Williams \& Wilkins, 1997:665-90. 19. Meyer, DR. Orbital fractures. In: Tasman W, Jaeger EA, eds. Duane' Foundations of Clinical Ophthalmology, 15th edn. Philadelphia: Lippincott Williams \& Wilkins, 2009: chap 48

20. Mackool RJ, Monsanto VR. Role of the bandage contact lens in the management of concomitant keratoconjunctivitis medicamentosa and cystoid macular edema. J Cataract Refract Surg 2002;28:1714.

21. Wilson FM II. Adverse external ocular effects of topical ophthalmic medications. Surv Ophthalmol 1979;24:57-88.

22. Chen W, Li Z, Hu J, et al. Corneal alterations induced by topical application of benzalkonium chloride in rabbit. PLoS One 2011;6:e26103.

23. Fraunfelder FW. Corneal toxicity from topical ocular and systemic medications. Cornea 2006; 25:1133-8.

24. Jin J, Chen H, Cao L. Management of conjunctival chemosis secondary to imatinib treatment for chronic myelogenous leukemia. Leuk Res 2009;33: e18-e19.

25. Fuentes V, de Frutos C, de Barrio M, et al. Unilateral conjunctival chemosis as a unique symptom of nonsteroidal anti-inflammatory drug intolerance. J Investig Allergol Clin Immunol 2007;17(1): 62-4.

26. Kyeong HK, Kim WS. Chronic unilateral chemosis following the use of amlodipine besylate. BMC Ophthalmol 2014;14:124.

27. Makani $\mathrm{H}$, Bangalore S, Romero J, Wever-Pinzon O, Messerli FH: Effect of renin-angiotensin system blockade on calcium channel blocker associated peripheral edema. Am J Med 2011;124(2):128-35.

28. Spalton DJ, Hitchings RA, Hunter PA. Atlas of Clinical Ophthalmology, 3rd edn. Oxford: Elsevier Mosby, 2004.
29. Krachmer JH, Mannis MJ, Holland EJ. Cornea: Fundamentals, Diagnosis, and Management, 3rd edn. New York: Elsevier Mosby, 2011.

30. Preechawat P, Narmkerd P, Jiarakongmun P, et al. Dural carotid cavernous sinus fistula: ocular characteristics, endovascular management and clinical outcome. J Med Assoc Thai 2008;91:852-8.

31. Ai J, Leonhardt JM, Heymann WR. Autoimmune thyroid diseases: etiology, pathogenesis, and dermatologic manifestations. J Am Acad Dermatol 2003;48:641-59.

32. Lemos J, Eggenberger E. Neuro-ophthalmological emergencies. Neurohospitalist 2015;5(4):223-33.

33. Kim SY, Kim MH, Cho YJ. Different clinical features of anaphylaxis according to cause and risk factors for severe reactions. Allergol Int 2018; 67(1):96-102.

34. Trivalle C, Doucet J, Chassagne P, et al. Differences in the signs and symptoms of hyperthyroidism in older and younger patients. J Am Geriatr Soc 1996 Jan;44(1):50-3.

35. Bartalena L, Pinchera A, Marcocci C. Management of Graves' ophthalmopathy: Reality and perspectives. Endocr Rev 2000;21:168-99.

36. Wiersinga WM, Bartalena L. Epidemiology and prevention of Graves' ophthalmopathy. Thyroid 2002;12:855-60.

37. Bartley GB, Fatourechi V, Kadrmas EF, et al. Clinical features of Graves' ophthalmopathy in an incidence cohort. Am J Ophthalmol 1996;121:284-90.

38. Saks ND, Burnstine MA, Putterman AM. Glabellar rhytids in thyroid-associated orbitopathy. Ophthalmic Plast Reconstr Surg 2001;17:91-5.

39. Kim BJ, Kazim M. Prominent premalar and cheek swelling: a sign of thyroid associated orbitopathy. Ophthalmic Plast Reconstr Surg 2006;22:457-60

40. Rice TW, Rodriguez M, Light RW. The superior vena cava syndrome: clinical characteristics and evolving etiology. Medicine 2006;85:37-42.

41. Tuy T, Peacock WF. Fluid overload assessment and management in heart failure patients. Semin Nephrol 2012;32(1):112-20.

42. McCloskey O, Maxwell AP. Diagnosis and management of nephrotic syndrome. Practitioner 2017;261(1801):11-5

43. Hull RP, Goldsmith DJ. Nephrotic syndrome in adults. BMJ 2008;336(7654):1185-9.

44. Kodner C. Diagnosis and management of nephrotic syndrome in adults. Am Fam Physician 2016;93(6):479-85

45. Ozbek S, Sert M, Paydas S, Soy M. Delay in the diagnosis of SLE: The importance of arthritis/arthralgia as the initial symptom Acta Med Okayama 2003;57(4):187-90.

46. Tomic D, Kemp WW, Roberts SK. Nonalcoholic fatty liver disease: current concepts, epidemiology and management strategies. Eur J Gastroenterol Hepatol 2018 Oct;30(10):1103-15.

47. Cheung O, Kapoor A, Puri P, et al. The impact of fat distribution on the severity of nonalcoholic fatty liver disease and metabolic syndrome. Hepatology 2007;46:1091-100.

48. Thomann KH. Syphilis. In: Marks ES, Adamczyk DT, Thomann KH, eds. Primary Eyecare in Systemic Disease. Norwalk, CT:Appleton \& Lange, 1995:404-16.

49. Fatourechi V. Pretibial myxedema: pathophysiology and treatment options. Am J Clin Dermatol 2005;6:295-309.50. Straka C, Ying J, Kong FM, Willey CD, Kaminski J, Kim DWN. Review of evolving etiologies, implications and treatment strategies for the superior vena cava syndrome. Springerplus 2016 Feb 29;5:229.51. Blendis LM. Jaundice in systemic disease. Baillieres Clin Gastroenterol 1989 Apr;3(2):431-45.52. Whiting E, McCready ME. Pitting and non-pitting edema. Med J Aust 2016; 205(4):157-8.

53. Bahn RS, Heufelder AE. Mechanisms of disease: pathogenesis of Grave's ophthalmopathy. N Engl J Med 1993;329:1468-75.

54. Peponis V, Chalkiadakis S, Ergin S, Kyttaris VC. Chemosis as a presenting symptom of systemic lupus erythematosus. Lupus 2010 Ju1;19(8):997-1001.55. Jankauskiene A, Buteikiene I. Severe chemosis in a patient with nephritic syndrome. Eur J Pediatr 2009;168(4):507-8

56. Glauser FL. Bilateral chemosis and conjunctival engorgement in cardiopulmonary failure. Chest 1974;66(4):389-94.

57. Srinivasan A, Biro NG, Murchison AP, et al. Efficacy of orbital color doppler imaging and neuroimaging in the diagnosis of carotid cavernous fistulas. Ophthalmic Plast Reconstr Surg 2016;33(5):340-4. 
58. Al-Mufti F, Amuluru K, El-Ghanem M, et al. Spontaneous bilateral carotid-cavernous fistulas secondary to cavernous sinus thrombosis. Neurosurgery 2017; 80(4):646-54.

59. Say EAT, Shields CL, Bianciotti C, Shields JA. Chronic conjunctival chemosis from amlodipine besylate (norvasc). Cornea 2011;30:604-7.

60. Williams ZR. Carotid-cavernous sinus fistulae: a review of clinical presentation, therapeutic options, and visual prognosis. Int Ophthalmol Clin 58(2):271-94

61. Desa V, Green R. Cavernous sinus thrombosis: current therapy. J Oral Maxillofac Surg 2012 Sep;70(9):2085-9162. Buckley EG. Cerebrovascular abnormalities. In: Wright KW, ed. Textbook of Ophthalmology. Baltimore, MD: Williams \& Wilkins, 1997:225-30.

63. Liu D. Conjunctivochalasis. Ophthalmic Plast Reconstruct Surg 1986;2:25-8.

64. Tse DT; Scott KR. The lacrimal system. In: Wright KW, ed. Textbook of Ophthalmology. Baltimore, MD: Williams \& Wilkins, 1997:367-89.
65. Welch J, Srinivasan S, Lyall D, Roberts F. Conjunctival lymphangiectasia: A report of 11 cases and review of literature. Surv Ophthalmol 2012;57(2):136-49.

66. Volek A, Toth J, Nagy ZZ, Schneider M. Evaluation of lymphatic vessel dilatations by anterior segment swept-source optical coherence tomography: case report. BMC Ophthalmol 2017;17:194.

67. Anders H, Keller C. Pemberton's maneuver - a clinical test for latent superior vena cava syndrome caused by a substernal mass. Eur J Med Res 1997;2:488-90.

68. Chapel TA. The variability of syphilitic chancres. Sex Transm Dis 1978;5:68-70.

69. Mindel A, Tovey SJ, Timmins DJ, Willaims P. Primary and secondary syphilis, 20 years' experience. 2 . Clinical features. Genitourin Med 1989 Jan;65(1):1-3.70. Chapel TA. The signs and symptoms of secondary syphilis. Sex Transm Dis 1980;7(4):161-4.

71. Campisi D, Whitcomb C. Liver disease in early syphilis. Arch Intern Med 1979; 139:365-6.

\section{HELP YOUR PATIENTS DISCOVER NEW VISION CARE OPTIONS}

\section{Our Co-Management program offers many advantages, including:}

- Access to any of our 30+ clinics across Canada

- A standardized Co-Management program

- Co-Management team available to facilitate patient care coordination

- An experienced team of surgeons who have collectively performed over 1 million procedures*

- We offer a wide range of vision correction options, including our PresbyVision ${ }^{\text {TM }}$ procedures, which are designed to correct presbyopia

(2) To book a free consultation for your patient, contact us directly at comanagement@lasikmd.com 